\title{
Impact of Green Finance on National Economic Growth During the COVID-19 Pandemic
}

\author{
Vijeta Singh ${ }^{1}$, Nandita Mishra ${ }^{2}$ (id ${ }^{\text {b }}$ \\ 1 School of Management-PG, MIT- World Peace University, India, 2 Department of Management and Engineering (IMI), Linkoping University, Sweden \\ Keywords: green finance, covid-19, economic growth, JEL G32 010 \\ https://doi.org/10.46557/001c.29975
}

\section{Energy RESEARCH LETTERS}

Vol. 3, Issue 3, 2022

This study explores the impact of green financing on economic growth during the COVID-19 pandemic. Using data from 30 countries, we find that green financing has a positive impact on economic growth. This finding has both theoretical and practical implications.

\section{Introduction}

With the aim of achieving the Sustainable Development Goals by 2030, policymakers, governments, and researchers are continuously seeking a solution that can provide ecological balance along with economic development. According to the International Finance Corporation, green finance is a financial innovation that will provide economic growth and environmental benefits. Green finance is attracting the attention of many countries (Zhang et al., 2019). Y. Wang \& Zhi (2016) define green finance as a fiscal model that combines economic development and environmental protection.

Various studies have explored the role of green finance in balancing economic growth and environmental protection. Broadly, these studies can be divided into two schools of thought. The first school argues that green financing has a negative impact on economic development (Wei \& Jinhua, 2014), while the second school argues that green financing enhances growth and recommends improvements in green financing systems (Haiyang, 2017). The second school has gained more support in the literature. For example, K. Wang et al. (2019), Chen et al. (2021), and He et al. (2019) contend that green finance has attributes that are similar to those of traditional finance, exemplifies environmental issues, and can help achieve economic growth. Hence, studies have started supporting green finance as an option to attain the Sustainable Development Goals (Dabyltayeva \& Rakhymzhan, 2019; Taghizadeh-Hesary \& Yoshino, 2019). Most of these studies point out that the major contributions to green investment have been made by the public sector.

Although several studies focus on fiscal development and economic growth, very few examine the impact of green finance on economic growth. In addition, given the economic and financial uncertainty induced by the COVID-19 pandemic, raising green funds has now become more challenging than ever. The COVID-19 pandemic has changed the scenarios and priorities of countries toward environmental issues. In response, this study is an attempt to understand the role of green financing in economic growth during the pandemic. Using a sample of 30 countries from high-, upper middle-, lower middle-, and lowerincome economies, we document that green financing has a positive impact on economic growth.

The study uniquely contributes to the literature by examining the contribution of green finance to economic growth. This helps in verifying whether green financing achieves its stated intention of balancing economic development and environmental issues. In addition, it unifies green finance, environmental benefits, and economic growth into one model and draws conclusions from it that are currently lacking in the literature. Furthermore, whereas prior studies focus on one country at a time, this study considers and compares 30 countries.

The remainder of the paper is arranged as follows. Section II outlines the data and the methodology. The analysis and interpretations are discussed in Section III. Finally, the study concludes in Section IV.

\section{Data and methodology}

The present study uses secondary data. The conceptual model's construction involves analyzing the impact of green spending in 30 countries on their economic growth against the background of the COVID-19 pandemic outbreak in 2020. The sample economies consist of 18 high-income economies (with a gross national income, or GNI, per

\footnotetext{
a vijju.golu@gmail.com

b Corresponding author: saanvinandita@gmail.com
} 
Table 1. Variable Description

\begin{tabular}{|c|c|c|c|}
\hline Variables & Short name & Description & Source \\
\hline $\begin{array}{l}\text { Log of Green Spending by } \\
\text { Governments (in USD } \\
\text { billion) }\end{array}$ & greenspend & $\begin{array}{l}\text { Cumulative spending by governments on green and } \\
\text { sustainable development projects in the year } 2020\end{array}$ & $\begin{array}{c}\text { Global Recovery } \\
\text { Observatory } \\
\text { Database }\end{array}$ \\
\hline $\begin{array}{l}\text { Inflation, Consumer } \\
\text { Prices (Annual \%) }\end{array}$ & Inflation & $\begin{array}{l}\text { It is percentage change in the cost to the average } \\
\text { consumer of having a basket of goods and services }\end{array}$ & World Bank \\
\hline $\begin{array}{l}\text { Exports of Goods and } \\
\text { Services (\% of GDP) }\end{array}$ & Exports & $\begin{array}{l}\text { The value of all goods and services provided to the rest } \\
\text { of the world }\end{array}$ & World Bank \\
\hline $\begin{array}{l}\text { Log of GDP Per capita } \\
\text { (Constant } 2010 \text { USD) }\end{array}$ & GDPpercapita & It is GDP divided by midyear population & World Bank \\
\hline $\begin{array}{l}\text { Gross capital formation } \\
\text { (Constant } 2010 \text { USD) }\end{array}$ & GCF & $\begin{array}{l}\text { It consists of outlays on additions to the fixed assets of } \\
\text { the economy plus net changes in the level of inventories. }\end{array}$ & World Bank \\
\hline Gross Debt as \% of GDP & Gdebt & $\begin{array}{l}\text { All liabilities of the country that requires future } \\
\text { payment of interests and principal. }\end{array}$ & $\begin{array}{l}\text { International } \\
\text { Monetary Fund }\end{array}$ \\
\hline
\end{tabular}

This table describes the variables and states the data sources.

capita of USD 12,696 or more), seven upper middle-income economies (with a GNI per capita of USD 4,096-12,695), four lower middle-income economies (with a GNI per capita of USD 1,046-4,095), and one low-income economy (with a GNI per capita of USD 1,045 or less). This income classification follows the World Bank Atlas method. The study employs the causal relation between green spending and other vectors of variables on the economic growth of select countries.

The data for green spending was extracted from the Global Recovery Observatory, a repository for data on global government spending during the COVID-19 crisis aimed at a sustainable impact and development. The data cover the fiscal spending of governments in the recovery from the after effects of the COVID-19 pandemic announced by 50 leading world economies. ${ }^{1}$ Of the 50 countries with data available for green financing, only 30 countries were selected, since the data for key explanatory variables were missing from the other countries. The explanatory variables comprise inflation to proxy for monetary policy, exports as a percentage of the gross domestic product (GDP) to proxy for external sector/trade, gross capital formation as a proxy for investment, and gross debt as a percentage of the GDP to proxy for fiscal health. The data period for the explanatory as well as explained variables correspond to the year 2020. The variable descriptions and their sources are provided in Table 1.

The dependent variable for green funding (in US dollars) is cumulative spending on clean archetype projects aiming at green growth and comprises green market creation (with the V and V-3 subtypes of capacity investments), clean research and development investment $(\psi)$, electric vehicle incentives, clean transport infrastructure investment $(\delta)$, clean energy infrastructure investment $(\eta)$, building upgrades and energy efficiency infrastructure investment $(\lambda)$ including other building upgrade support $(\lambda 3)$, natural in- frastructure and green space investment $(\mu)$, including the subcomponents of tree planting and biodiversity protection $(\mu 2)$, ecological conservation initiatives $(\mu 3)$, and an agricultural uplift ( $\mu 5)$, and finally, local (project-based) infrastructure investment $(\theta)$ including the subcomponent of investment in clean new housing $(\theta 3)$. With the above variables, we construct the following empirical model:

$$
\begin{aligned}
\text { GDPpercapita }_{i}= & \alpha+\beta_{1} \text { greenspend }_{i}+\beta_{2} G C F_{i} \\
& +\beta_{3} \text { Gdebt }_{i}+\beta_{4} \text { Inflation }_{i} \\
& +\beta_{5} \text { Exports }_{i}+\varepsilon_{i}
\end{aligned}
$$

where $\alpha$ represents the intercept, $\beta$ represents the slope coefficients, and $\varepsilon$ is the error term. The variables are outlined in Table 1.

\section{Analysis and interpretation \\ A. Data description}

The summary statistics and correlations between the variables are provided in Table 2 . The results show that the green spending, inflation, and exports to the GDP of various countries are quite distinct. The reason could be that different countries have different economic conditions and priorities.

Panel B of Table 2 presents the correlation matrix for the model. The logarithm of green spending and the logarithm of the GDP per capita are weakly positively related, with a correlation of 0.48 , while gross capital formation and the logarithm of green spending are also positively related (0.42). Exports as a percentage of the GDP are, as expected, positively correlated with the GDP per capita, indicative of the positive contribution of exports to the economy. Inflation rates, as expected, are negatively correlated to the GDP per capita (-0.32) and exports as a percentage of the GDP $(-0.308)$, respectively.

1 More details can be obtained from https://recovery.smithschool.ox.ac.uk/tracking/. 
Table 2. Descriptive statistics and correlation matrix

\begin{tabular}{|c|c|c|c|c|c|c|}
\hline \multicolumn{7}{|c|}{ Panel A: Descriptive Statistics } \\
\hline Variable & & $N$ & Mean & SD & Min & Max \\
\hline Log of GDPPC & & 30 & 9.748 & 1.36 & 6.744 & 11.417 \\
\hline Log of Green Spending & & 30 & .445 & 2.247 & -4.605 & 4.021 \\
\hline Gross Capital Formation & & 30 & $3.86 e+11$ & $9.69 e+11$ & $2.24 \mathrm{e}+09$ & $5.37 e+12$ \\
\hline Gross Debt as \% of GDP & & 30 & 77.352 & 30.672 & 32.542 & 155.562 \\
\hline Inflation & & 30 & 3.167 & 6.949 & -1 & 36.1 \\
\hline Exports as $\%$ of GDP & & 30 & 39.008 & 24.735 & 9.578 & 127.64 \\
\hline \multicolumn{7}{|c|}{ Panel B: Matrix of Correlations } \\
\hline Variables & (1) & (2) & (3) & (4) & (5) & (6) \\
\hline (1) Log of GDPPC & 1.000 & & & & & \\
\hline (2) Log of Green Spending & 0.487 & 1.000 & & & & \\
\hline (3) Gross Capital Formation & -0.062 & 0.423 & 1.000 & & & \\
\hline (4) Gross Debt as \% of GDP & -0.020 & 0.086 & 0.008 & 1.000 & & \\
\hline (5) Inflation & -0.324 & -0.164 & -0.118 & 0.029 & 1.000 & \\
\hline (6) Exports as \% of GDP & 0.539 & -0.057 & -0.189 & -0.184 & -0.308 & 1.000 \\
\hline
\end{tabular}

This table reports descriptive statistics and the correlation between variables of the variables. The statistics are number of observations (N), mean (Mean), standard deviation (SD), minimum (Min), and maximum (Max). The sample covers 30 countries.

\section{B. Regression results}

The study employs ordinary least squares (OLS) and a robust regression method to estimate the proposed model. The robust regression method employed as a preliminary inspection of the model noted the presence of outliers. Further, for the OLS model, specific diagnostic tests are performed to check for multicollinearity (variance inflation factor) and heteroscedasticity (Breusch-Pagan/Cook-Weisberg test), as well as link tests, to check for specification errors and omitted variables (through Ramsey's regression equation specification error test or RESET). The primary motive behind the use of robust regression was to remove influential observations from the model, since high leverage points in the latter can have a significant effect on the estimates obtained for the regression coefficients. Table 3 shows the OLS regression and robust regression results.

The preliminary identification of significant outliers is carried out through leverage versus squared residual plots.

The results show that, of the 30 countries in the sample, Argentina and China are influential outliers. Further, Cook's distance $\left(D_{i}\right)$ is calculated to check for statistically significant outliers, and Argentina and China, with Cook distances of 2.93 and 3.45, respectively, are significant outliers. Countries with a Cook's distance $D_{i}$ greater than one are considered influential outliers (Verardi \& Vermandele, 2018), which works well in practice. Cases with $D_{i}$ greater than one (Argentina and China in this case) are assigned weights of zero with respect to the difference between predicted and actual values. The large absolute residuals are weighted less, and small absolute residuals are weighted more; thereafter, robust regression is run using generated weights.

Panels A and B of Table 4 show, respectively, the results for the OLS and robust regressions. These results suggest that green spending by governments has a statistically significant and positive impact on the GDP per capita of the sample countries (see Table 4), indicating that the financing of green projects can lead to economic growth (Jiang et al., 2020; X. Wang \& Wang, 2020). Further, as an external sector variable, exports as a percentage of the GDP positively impact economic growth in both the models employed, primarily in the form of significant inflows of foreign exchange and appreciation of foreign exchange reserves contributing to the national Exchequer. Many studies have vouched for the role of exports in strengthening the GDP of a country (Emery, 1967). Our study also concludes that inflation has a negative impact on the GDP per capita, with a $t$-value of -1.81 . Andres \& Hernando (1997) have empirically investigated the negative impact of inflation on economic growth.

The diagnostic test for the OLS model is primarily aimed at detecting the presence of non-orthogonality in the explanatory variables and model specification issues. The mean value for the variance inflation factor for the OLS model is 1.19, indicating the absence of multicollinearity, while the link test results (for specification errors) have a $(\hat{Y})^{2}$ value of -1.44 , meaning the model is correctly specified. The Ramsey RESET for omitted variables indicates the presence of an omitted variable as $P r o b>F 0.0063$ (with an $H_{0}$ indicating no omitted variable bias); however, the Breusch-Pagan/Cook-Weisberg test for heteroscedasticity (with an that assumes constant variance) has Prob $>\chi^{2}$ 0.0488 and, hence, indicates the presence of heteroscedasticity.

\section{Conclusion}

This paper attempts to examine empirically the impact of green financing on the economic growth of different 
Table 3. Regression results

\begin{tabular}{|c|c|c|c|c|}
\hline \multicolumn{5}{|c|}{ Panel A: OLS regression results } \\
\hline Variables & Coefficient & S.E. & t-value & p-value \\
\hline Log of Green Spending & 0.360 & 0.087 & 4.15 & $0.000^{* * *}$ \\
\hline Gross Capital Formation & 0.000 & 0.000 & -1.59 & 0.126 \\
\hline Gross Debt as \% of GDP & 0.001 & 0.006 & 0.20 & 0.846 \\
\hline Inflation & -0.020 & 0.027 & -0.73 & 0.475 \\
\hline Exports as \% of GDP & 0.028 & 0.008 & 3.56 & $0.002^{* * *}$ \\
\hline Constant & 8.609 & 0.648 & 13.29 & $0.000^{* * *}$ \\
\hline R-squared & 0.606 & & $\mathrm{~N}$ & 30 \\
\hline F-test & 7.397 & & Prob $>\mathrm{F}$ & 0.000 \\
\hline \multicolumn{5}{|c|}{ Panel B: Robust regression results } \\
\hline Variables & Coefficient & S.E. & t-value & $\mathrm{p}$-value \\
\hline Log of Green Spending & 0.329 & 0.122 & 2.69 & $0.013^{* *}$ \\
\hline Gross Capital Formation & 0.000 & 0.000 & -0.62 & 0.542 \\
\hline Gross Debt as \% of GDP & -0.003 & 0.007 & -0.35 & 0.728 \\
\hline Inflation & -0.142 & 0.079 & -1.81 & $0.084^{*}$ \\
\hline Exports as \% of GDP & 0.020 & 0.009 & 2.18 & $0.040^{* *}$ \\
\hline Constant & 9.557 & 0.851 & 11.23 & $0.000^{* * *}$ \\
\hline R-squared & 0.587 & & $\mathrm{~N}$ & 28 \\
\hline F-test & 6.254 & & Prob $>\mathrm{F}$ & 0.001 \\
\hline
\end{tabular}

This table shows the robust regression estimates. The dependent variable is Log of GDPPC. ${ }^{* * * *} \mathrm{p}<0.01,{ }^{* * *} \mathrm{p}<0.05,{ }^{*} \mathrm{p}<0.1$ symbolize level of significance. S.E. denotes standard errors.

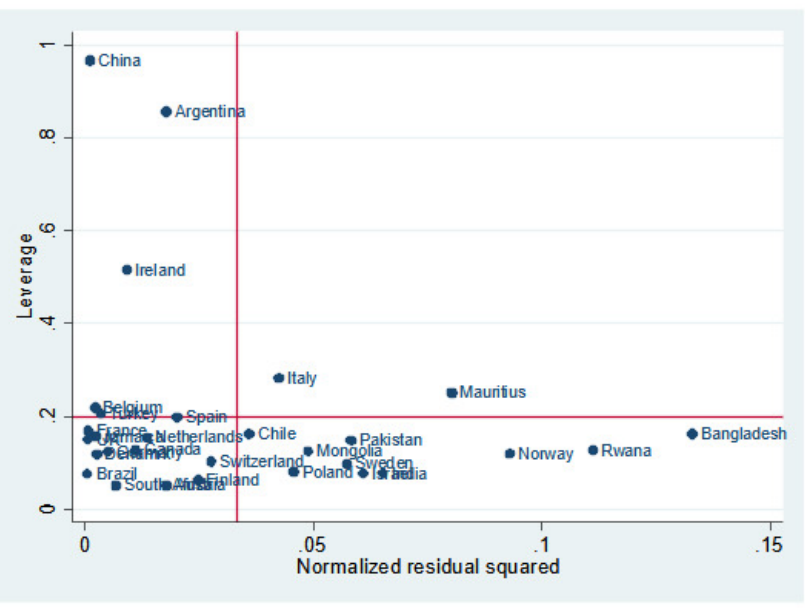

Figure 1. Leverage vs. squared residual plot

countries during the COVID-19 pandemic. The results show a positive impact of green financing on the GDP per capita for the sample countries, in line with the previous literature
(Greco, 2018; Haiyang, 2017). The study also finds that exports as a percentage of the GDP has a positive impact on economic growth, whereas inflation has a negative impact on the GDP per capita. The model indicates that green financing can improve the economic development of countries, creating a win-win situation, and governments should therefore focus on green project financing by integrating it into economic recovery plans.

Amid two schools of thought, this study supports investment in green financing, adding to the literature review. The paper also has implications for policymakers and government bodies. The relevant national and international bodies should combine the features of different countries and frame an appropriate green financial policy to promote universal green development. They should also determine how green finance can accelerate green development at the national level, which will provide much needed impetus for global green recovery after the COVID-19 pandemic. 


\section{References}

Andres, J., \& Hernando, S. (1997). Does Inflation Harm Economic Growth? Evidence for the OECD. NBER Working Paper, w6062.

Chen, C., Zhang, Y., Bai, Y., \& Li, W. (2021). The impact of green credit on economic growth-The mediating effect of environment on labor supply. PLOS ONE, 16(9), e0257612. https://doi.org/10.1371/journal.pon e.0257612

Dabyltayeva, N., \& Rakhymzhan, G. (2019). The green economy development path: Overview of economic policy priorities. Journal of Security and Sustainability Issues, 8(4), 643-651. https://doi.org/10.9770/jssi.201 9.8.4(8)

Emery, R. F. (1967). The relation of exports and economic growth. Kyklos, 20(4), 470-486. https://do i.org/10.1111/j.1467-6435.1967.tb00859.x

Greco, F. (2018). Resilience: Transform adverse events into an opportunity for growth and economic sustainability through the adjustment of emotions. Business Ethics and Leadership, 2(1), 44-52. https://do i.org/10.21272/bel.2(1).44-52.2018

Haiyang, Q. (2017). Research on the Economic Growth Effect of Green Finance. Economic Research Reference, 38, 53-59. https://doi.org/10.16110/j.cnki.issn2095-3 151.2017.38.007

He, L., Liu, R., Zhong, Z., Wang, D., \& Xia, Y. (2019). Can green financial development promote renewable energy investment efficiency? A consideration of bank credit. Renewable Energy, 143, 974-984. http s://doi.org/10.1016/j.renene.2019.05.059

Jiang, L., Wang, H., Tong, A., Hu, Z., Duan, H., Zhang, X., \& Wang, Y. (2020). The measurement of green finance development index and its poverty reduction effect: Dynamic panel analysis based on improved Entropy method. Discrete Dynamics in Nature and Society, 2020, 1-13. https://doi.org/10.1155/2020/885 $\underline{1684}$
Taghizadeh-Hesary, F., \& Yoshino, N. (2019). The way to induce private participation in green finance and investment. Finance Research Letters, 31, 98-103.

Verardi, V., \& Vermandele, Cc. (2018). Univariate and Multivariate Outlier Identification for Skewed or Heavy-Tailed Distributions. The Stata Journal, 18(3), 517-532. https://doi.org/10.1177/1536867x180180030 $\underline{3}$

Wang, K., Tsai, S. B., Du, X., \& Bi, D. (2019). Internet finance, green finance, and sustainability. Sustainability, 11(14), 3856. https://doi.org/10.3390/s $\underline{\mathrm{u} 11143856}$

Wang, X., \& Wang, S. (2020). The Impact of Green Finance on Inclusive Economic Growth. Open Journal of Business and Management, 08(5), 2093-2112. http s://doi.org/10.4236/ojbm.2020.85128

Wang, Y., \& Zhi, Q. (2016). The role of green finance in environmental protection: Two aspects of market mechanism and policies. Energy Procedia, 104, 311-316. https://doi.org/10.1016/j.egypro.2016.12.05 $\underline{3}$

Wei, N., \& Jinhua, S. (2014). An Empirical Study on the Dynamic Relationship between Green Finance and Macroeconomic Growth. Seeker, 8, 62-66. https://do i.org/10.16059/j.cnki.cn43-1008/c.2014.08.050

Zhang, D., Zhang, Z., \& Managi, S. (2019). A bibliometric analysis on green finance: Current status, development, and future directions. Finance Research Letters, 29, 425-430. https://doi.org/10.101 6/j.frl.2019.02.003 